The Lords committee warns that there is a danger of Britain becoming complacent about the need to develop alternatives to the internal combustion engine because the availability of North Sea oil might make petrol-run cars economic in Britain after they have ceased to be so in other countries. The committee recommends that the government encourage electric vehicle manufacturers to continue their research at least at the present level, which it finds satisfactory, by continuing to give financial support matched in some way to the manufacturers' own investment. Government should also be prepared to make productlaunch money available "to get over the volume-production lump in the next few years". The committee does not, however, suggest that electric vehicle research be centrally planned, finding the present system of manufacturers applying for grants on an ad hoc basis satisfactory. It has seen no evidence of any overlap of research.

There is one area, however, in which the Lords say that more work could be done. Hybrid vehicles, propelled by a combination of battery and internal combustion engine, are being vigorously explored in Japan and the USA, but have so far received little attention in Britain. They offer the most promising prospects for private use by overcoming the pure electric car problem of short range, typically 50-70 miles. They also do not necessarily depend on the development of new advanced batteries. A major disadvantage, leading to high capital cost, is that incorporating two different propulsion systems in one vehicle is technically very difficult. Nevertheless, the government should be prepared to make a "small" amount of public money available for testing them, says the committee.

The future of electric vehicle development lies with large companies prepared and able to invest heavily in research and development and not with small businesses set up to build one or two specialized vehicles, says the report. So far, the manufacturers of batteries and components, such as Lucas and Chloride, have invested much more than the major car manufacturers. A possible reason, put to the committee by BL Technology, a subsidiary of British Leyland, is that vehicle manufacturers add only 30 per cent of the final value of an electric vehicle, the electrical component manufacturers standing to win the biggest reward.

The committee hopes that the car manufacturers will eventually be enticed to invest in electric vehicle development by the prospect of major markets in countries which, unlike Britain, cannot rely on a steady supply of oil into the 1990 s. It would be a pity, it says, if Britain were to lose its lead in electric vehicle technology now, only to be forced later into buying from abroad because it had been lulled into a false sense of security in the 1980s.

Judy Redfearn

\section{Using less}

\section{Washington}

Officials at the Department of Energy appear to share with the superstitious the view that to talk about good luck is to ensure that it will disappear - “don't count your blessings" and all that. Accordingly, not much is being made of the dramatic reduction of crude oil imports to the United States in the past year, which in the first eight months are down by $\mathbf{1 7 . 2}$ per cent between 1979 and 1980 .

According to the Department of Energy's Weekly Petroleum Status Report for 29 August, imports of crude oil and refined products averaged 6,907 million barrels a day in the first 234 days of 1980 , compared with a total of 8,341 million barrels a day in 1979. If this keeps up, President Carter's promises at the Venice summit on oil imports will be amply fulfilled.

The diffidence of the statisticians responsible for the weekly statistics is partly technical. The weekly Status Report, although admirably up to date, is based on returns from oil companies and crude oil refiners, and is therefore not a direct measure of actual consumption. Perhaps, it is said, the reduction of imports reflects reduced inventories in the distribution network. The rapid attritition of gasoline service stations certainly implies that many retailers' gasoline tanks have been emptied for the last time. The statisticians appear not to dare to take heart from the

\section{US petroleum}

supposition that most retailers going out of business are doing so because they are selling less.

The statisticians are also diffident because they do not understand why the most recent round of price increases for petroleum products should have demonstrated, after a decade of apparent price inelasticity, that even Americans will buy less gasoline and fuel oil if the price goes up sufficiently. Could it even be that some non-quantifiable consideration, such as the continued presence of American hostages in Iran, has changed people's buying habits?

Whatever the truth, the facts are clear. Between the first eight months of 1979 and the corresponding period this year, gasoline production for the US market has declined by 6.8 per cent, to an average of 6.6 million barrels a day (still more than a third of total volumetric production of 17.6 million barrels a day of all oil products). Distillate fuel oil is also down by 14.2 per cent, partly because householders and commercial consumers have turned down their thermostats, partly because oil companies are chafing at state and even more local price restrictions. Already there are fears that if the coming winter is cold, it may also be hard. oil and of petroleum products have soared. Primary commercial stocks have increased by more than ten per cent in the past year. Gasoline is in especially good supply. Fuel oil is, however, short.

The most obvious disappointment in the statistics so far available for 1980 is that US oil production has hardly changed since
During the same period, stocks of crude

\section{Saturn seen in Voyager sights}

The accompanying photograph, released at the end of August from the Jet Propulsion Laboratory in California, is one of the first to have been gathered from the spacecraft Voyager 1, now on its way from Jupiter to Saturn. Between 22 August, when the first photographs were obtained, and 24 October, visual observation from Voyager 1 will consist entirely of single-frame photographs. Thereafter, the narrow-angle camera on the spacecraft will be used to collect mosaic photographs of the visible surface of Saturn and of the rings and to search for satellites at present unknown.

The closest approach to Saturn will occur on 12 November, when the space- Saturn from Voyager 1 on 24 August, 1980. craft will also come closest to the satellites The dark band on the equator is the shadow Tethys, Mimas and Enceladus. The of this rings. The three bright specks are closest approach to Titan, one of the satellites.

principal targets for the cameras, will occur on 11 November. Visual observation of Saturn will continue at least until 18 November.

Visual observations are, of course, merely the most memorable of the observations made by planetary spacecraft. Voyager 1 is also equipped with magnetometers, infrared sensors (which will, in particular, produce a map of the surface of Saturn) and devices for recording the interplanetary particle flux and for measuring the size and density of material particles in the rings of Saturn. 